\title{
A New Governance Model for Independent Regulatory Agencies
}

\author{
Rui Nunes*, Sofia B. Nunes, Guilhermina Rego \\ Department of Social Sciences and Health, Faculty of Medicine, University of Porto, Porto, Portugal \\ Email: ruinunes@med.up.pt
}

Received 5 January 2015; accepted 18 January 2015; published 19 January 2015

Copyright (C) 2015 by authors and Scientific Research Publishing Inc.

This work is licensed under the Creative Commons Attribution International License (CC BY). http://creativecommons.org/licenses/by/4.0/

c) (i) Open Access

\section{Abstract}

In a regulatory state the purpose of intervention by any Independent Regulatory Agency (IRA) is not only regulation in the strict sense but also the supervision of the activity of institutions providing a specific service, particularly the utilities. However, given the evolution of most market economies, namely in transition countries, it is necessary to design new governance arrangements that enable an effective, transparent and truly independent intervention of IRAs. The objectives of this study are a) to analyse of the institutional-design chosen for some independent regulatory agencies and its regulatory framework, namely in northern economies, and b) to suggest the need to strengthen governance arrangements to effectively guarantee regulatory independence, transparency and accountability, therefore promoting a true sunshine regulation in southern economies. The authors conclude that strengthening accountability arrangements is the most important mechanism to avoid regulators capture from the government and regulated organisations. It is also concluded that the way regulators have chosen can also influence the way IRA conducts its activity. Therefore, it is suggested that board accountability can be enhanced by the generalization of the principle of the public contest of regulators.

\section{Keywords}

Accountability, Independent Regulatory Agencies, Regulatory State of the South, Sunshine Regulation

\section{Introduction}

Over the past few decades the market economy has led to the need to implement in most developed countries a clear separation of the state's regulatory and supervisory role in relation to its functions as an operator and a

${ }^{*}$ Corresponding author. 
financier in various economic activities through the establishment of different institutional mechanisms, namely the creation of dedicated regulatory bodies [1]. The aim was to give strong independence to the regulatory agencies in order to effectively separate these functions and ensure the independence of the regulation both in relation to the state operators and operators in general. Thus, the purpose of intervention by any independent regulatory agency (IRA) is not only regulation in the strict sense, but also the supervision and monitoring of the activity of institutions providing a specific service (the utilities in particular).

Given the evolution of most market economies, an important issue is to determine if actual governance arrangements should be strengthened to enable an effective, transparent and truly independent intervention of independent regulatory agencies and also how governance arrangements should be strengthened [2]. This is a rather important question because without a full guarantee of independence market competition is compromised and efficiency will be undermined. The weaknesses of some governance models must be analysed so that suggestions can be made to increase the overall efficacy of IRAs. If the "regulatory state" in the north is under considerable stress from the global financial crisis, the consequences of the regulatory state in south economies remain to be seen. In this changing economic and political context, a broader conversation around the role of the regulatory state in both north and south could be stimulated, namely in developing countries. The regulatory state in the north is under considerable stress from the global financial crisis. Understanding this evolution could be an important step to promote a new regulatory state of the south.

This study will depart from well-established stakeholders and principal-agent theories, so that an applicable set of principles is used in national or even transnational approaches to economic and social regulation. Indeed, for many years there is a consistent set of principles in economic as well as social regulation. From an economic perspective, Ayres and Braithwaite [3] and Baldwin and Cave [4] have determined the best strategies and the practical rules of responsive regulation. Also, Aguilera, Filatotchev, Gospel and Jackson [5] propose an organizational approach to comparative corporate governance demonstrating the balance that should exist between governance and regulation. Thatcher [6]-[8] has even suggested the optimal approach to delegation to independent regulatory agencies, namely in developed countries, and the need to contextualize the activity of independent regulatory agencies to specific political contexts and economic arrangements.

On the other hand, Dubash [9] made a bridge between the rise of the regulatory state and the emerging economies of the south, and what should be learned from past experiences. In this vein, this study intends to accomplish a set of specific objectives, namely,

a) To analyse the institutional-design chosen for some independent regulatory agencies and the respective regulatory framework namely in northern economies;

b) To suggest the need to strengthen governance arrangements to effectively guarantee regulatory independence, transparency and accountability, therefore promoting a true sunshine regulation in southern economies.

\section{Independence in Regulation}

The evolution felt in different areas of economic activity led to the creation of regulatory agencies "dedicated" to a particular sector of activity and applying the model of independent regulatory authorities to it. That is, independent of the government, thus emphasising the separation between the operator/provider state and the regulatory state [10] [11]. Thus, it becomes possible to guarantee to private operators that the regulation is not influenced by the interests of the state as operator, or as market agent. The option for non-governmental regulatory bodies (independent) or government entities (direct or indirect administration) and the allocation of regulatory powers depend on a number of variables. As stated by Majone, "independent regulatory agencies have been established also in order to protect the regulatory process from such political uncertainty. In this perspective, the independent regulator may be viewed as an impartial referee administering a regulatory contract in the interest of all the stake holders. Thus, the challenge facing legislators is to design a framework where independence and accountability are complementary and mutually supportive, rather than mutually exclusive, values... Agency independence is not an end in itself, rather it is a means for achieving higher-level objectives such as policy coherence, credibility, and accountability. In political terms an independent regulatory agency provides assurance both to the current majority and to future ones that their policies will be implemented impartially, as well as in a technically and economically competent way. The assumption that the agency operates at arm's length from government is of course essential" [12].

It should be pointed out that competition should never be viewed as an end in itself but as a means of adding value to economic activities and to regulate the activity of different companies in different sectors of activity. 
Independent regulation is an important tool to guarantee that there is a healthy and effective competition in the provision of utilities (energy, transport, telecommunications, water, etc.), or even in sectors of activity of great ethical and social impact such as healthcare [13]. A company is considered to be any entity engaged in an economic activity consisting of offering goods or services in a given market, regardless of its legal status and operating mode.

The main characteristics of independent regulation can be summarised as follows [14]:

1) Public Interest: The main goal of regulation is performance improvement having as background the public interest in protecting a major social or economic good. Promoting competition through market approaches is another important objective;

2) Authority: The regulator is recognised as such by all stakeholders and there is a specific legal framework for its activity;

3) Centralisation: Control, supervision, and monitoring of any specific market is centralised to assure the best regulatory outcome;

4) Independence: To produce the best regulatory outcome the regulator is financially, organically and functionally independent from the government and regulated organisations. The regulator is also independent from any economic player in a specific sector;

5) Regulatory Governance: The regulator is an exterior entity with regards market activities and should be accountable to society in a fair and transparent way, namely to the Parliament Select Committee or other democratic institutions.

But, to be effective, independent regulation should be complemented with a wide range of powers for administrative supervision and monitoring the system, so that the regulatory activity is implemented effectively. In addition to independence, authority is therefore another essential feature of the regulation and the IRAs should have the following powers statutorily:

1) Regulatory Powers: In the exercise of regulatory powers over the services and entities subject to regulatory activity, the IRAs should issue recommendations and directives, promote compliance with the safety and quality regulations, and promote compliance with the codes of conduct, best practice guides and users' charters of rights of the establishments and services;

2) Supervisory Powers: In the exercise of their supervisory powers, the IRAs should keep the legally required records, grant authorizations and approvals in the cases legally foreseen, issue orders and instructions, as well as recommendations or warnings, where necessary, supervise the implementation of laws and regulations and other rules applicable to the activities subject to their regulation;

3) Investigative and Sanctioning powers: In the exercise of their investigative and sanctioning powers, the IRAs can request all needed information and can trigger the sanction procedures in the event of administrative offenses, adopt the necessary provisional measures and apply appropriate sanctions, report to the competent authorities the offenses whose punishment are not within their competence and propose, as part of their duties, suspension or revocation of the license of establishments of the regulated sector.

In the absence of a single model of regulatory authorities in market economies, it is important to contextualise different institutional designs according to the most modern regulation perspectives [4]. The foundations of regulatory independence are thus focused on a set of key assumptions:

1) Separation between the political sphere and the economic sphere;

2) Ensure the stability and security of the regulatory framework;

3) Encourage professionalism and political neutrality;

4) Separate the operator state from the regulatory state;

5) Prevent the regulator's capture.

The independent regulation aims to avoid the "regulator's capture" by the political power, the corporate power or the economic power. This is to avoid an illegitimate influence in the regulatory sphere, particularly during the decision-making process [15] (Kon, 2003). In fact, the creation of independent regulatory agencies is one of the distinctive features of the emergence of the regulatory state in developed countries over the past decades. Although there is no consensual definition of "agency", the most comprehensive definition is probably the one provided by the US Administrative Procedure Act. According to this definition of the United States federal agencies, "an agency is a part of government that is generally independent in the exercise of its functions and that by law has authority to take a final and binding action affecting the rights and obligations of individuals, particularly by the characteristic procedures of rulemaking and adjudication". 
In Gilardi's opinion, though IRAs are nonmajoritarian institutions because they do not depend directly on the popular vote, they were widespread in liberal democracies, particularly because they largely overcome the problem of lack of credibility of the political power and so solve the uncertainty seen in democratic alternation. Stability then becomes the paradigm of independent regulation and regulators become important symbols of moral authority of the state [16]. Independent regulatory agencies are not directly accountable to the voters and hence do not enjoy direct democratic legitimacy, but they do enhance the quality of democracy by overcoming political uncertainty. In short, IRAs are public administrative agencies, organically and functionally independent from the government (and not merely autonomous), agencies that indirectly follow general policy goals determined by voters. Although IRAs are not part of the government stricto sensu they are considered part of the state as they are accountable to the parliament or other democratic institution.

The organic and functional independence of regulatory authorities is also guaranteed by the method of financing their activities. In fact, most of the independent regulators are funded essentially by own revenues i.e. from fees charged to operators and not by taxpayers taxes. However, there should exist important mechanisms for internal and external control-regulatory governance - to prevent the concept of independence being confused with discretionary or arbitrary exercise of regulatory power.

Economic independence and political independence are part of an indivisible whole, given the theoretical possibility of the government reducing the resources for the operational management of the regulatory bodies, and through financial asphyxiation, indirectly influence its activity. By ensuring the economic and financial independence, both in terms of funding sources and with regard to financial management, interference in the activity of IRAs becomes just residual. Most IRAs charge each operator a "supervision fee"-whether it is a market with multiple operators or a market with a small number of agents - a fee which is fully justified by the function of monitoring the market, a standard practice in another type of regulatory agencies, such as central banks. At stake is the application of a fee (and not a tax), since an IRA, by supervising a particular market in terms of competition, quality, etc., is providing a service to individual operators. For example, issuing a recommendation, even if at the IRA's own initiative, has widespread reach to all operators.

On the other hand, transparency and accountability are important factors to guarantee IRAs independence. In this context by accountability it is meant the duty to disclose relevant information and the rationale for decisionmaking. It implies a practice of transparency in regulation so that different players have access to the same level of information. In other words, society, and the various agents in the sector concerned, have the right to access in real time - for example through the internet - to any sort of data that is not classified. Thus, standardisation is instrumental to the achievement of good regulatory governance. Independence is also guaranteed by the necessary incompatibilities of the members of the board of directors (e.g. not from corporations or unions), and by the periods of "quarantine" at the end of their term of office (cannot accept positions in regulated activities). For all these reasons, good governance of the regulatory entities is fundamental Transparency and accountability is therefore indirect indicators of independence [17].

If the IRAs is managed by collegiate bodies the president of the board of directors is just primum inter pares. Whatever the appointment method and the governance arrangement of the IRA, the board has specific powers and all members of the board of directors, and not just the president, must be chosen with guarantee of full independence and impartiality. Given the constant demands of society in relation to the method of appointing regulators, and to dispel any doubt about their impartiality and fairness, the possibility of implementing the principle of appointing regulators as a result of public contest should be seriously considered. Involving the parliament or any other elected institution (in parliamentary, presidential or mixed political systems) in this tender procedure would definitely safeguard one of the main criticisms of independent regulators, which is the plausibility of capture of the regulator by the political power or by economic agents.

As a general rule it should be pointed out that, as the IRAs are nonmajoritarian institutions in democratic politics, the existence of mechanisms for internal and external operational control is essential. The transparency of the decision-making processes and their rationale is of the greatest relevance to ensure citizens a total equity in the treatment of complex relationships that develop in the society, in particular those which relate to compliance with the rules of the competitive market. It would be great for democratic transparency, if the Parliament Select Committee or other democratic institutions carried out closer monitoring of regulators. More than the method of appointment of governing bodies, hearing in parliamentary committee is fundamental for effective monitoring of the performance of independent regulatory authorities. The independence of regulatory authorities does not make them immune to parliamentary monitoring. Parliamentary monitoring at committee level, less politicised 
and more technical, may be appropriate compensation for the absence of government control.

With regard to the IRAs, the governance mechanisms and the respective control of activity should have essentially two dimensions: internal and external control. The internal control of activity may be exercised by distinct pathways. On the one hand, by the nature of the board of directors that, being collegiate (a president and two or more members), implies that decisions are by majority, preventing any totalitarian temptation on the part of one of its members. On the other hand, the statutory auditor should have the task of ensuring the legality and the economy of financial and asset management.

Although disputable another internal control mechanism might be the establishment of an advisory board composed of representatives of institutions such as professional associations, public agencies, representatives of users and representatives of other associations of the regulated sector. But the existence of an advisory board is rather controversial because of the possible trade-off between expertise and independence from the sector. More important than setting up a body of this nature is to hear the stakeholders, whoever they may be, and willingly accept their suggestions or complaints as long as independence is not compromised.

The external control of an IRA activity can be made by using general supervisory mechanisms and specific mechanisms through the intervention of democratically elected politicians. For instance the parliament, the ministry that holds authority over the regulated sector or even the ministry of finance should exercise appropriate control, in particular with respect to the approval of the plan of activities, the activity report, the budget, the balance sheet and the annual management accounts. It may also intervene by granting authorisation for the acquisition, sale and financial leasing of immovable property for the installation, equipment and functioning of the IRA. It should be emphasised that the suggestion of this external control is only to guarantee the legality of the procedures and the conformity with the overall sectorial policy (democratically determined) albeit within a framework of great organic and functional independence.

Moreover, the parliament or other democratic institution, in addition to monitoring the activity developed by the IRA, through hearings in the Parliament Select Committee or parliamentary inquiry (or equivalent in nonparliamentary systems), is responsible for assessing and approving the budget in the context of State Budget Bill and IRA accounts within the framework of the General State Accounts. Also the judicial system allows individuals to request judicial review of the IRA's administrative activity, within the scope of its responsibilities, as well as the decisions to apply fines and other sanctions in infringement proceedings.

Despite political accountability being somewhat diluted, this can be accomplished through a strict control in the Parliament Select Committee, the highest body in the exercise of democratic power in many political systems. Furthermore, the appointment of regulators as a result of public tender can decisively contribute to the credibility of these authorities. Not that supervision by Parliament is not essential, it is. Even though this supervision can be exercised pre-emptively, beforehand, through parliamentary hearing of the governing bodies prior to their appointment, Parliament should be responsible for the constant supervision of the sectorial regulatory activity. As we will see below, another social transparency mechanism is the requirement of publication of an annual report of activities and its disclosure through the proper channels. Moreover, the performance of the regulatory authorities can and should be periodically assessed by the Parliament Select Committee.

Independence depends on a large set of variables but the scrutiny that all stakeholders can make over any IRA activity is decisive for achieving independence. It is definitely not just the appointment method that evaluates the conduct of regulators. At best, it will be the control mechanisms, already referred to, that will guarantee independence from the different market agents, especially the large economic and financial groups. Also, the greater the personal authority and prestige of the regulator the safer is its independence from external pressures. Therefore, the appointment method should maximise these characteristics in the context of a new regulatory governance especially in countries that are beginning to implement independent regulation.

\section{Regulatory Governance and Accountability}

The emergence of regulation independent of political power - in a plural democracy - immediately raises the issue of determining the mechanisms for controlling its activity. If the formal legitimacy of this regulatory model is not questionable, then there should emerge instruments that would enable society to monitor the performance of independent regulators [18]. In the context of a growing economic and cultural globalization, this problem is not specific to regulatory authorities, but extends to all organisations including big corporations and other organisations. What is at stake is to find a form of social accountability of the different economic agents in

complex inter-organisational relationships that now occur in an increasingly open and competitive economy [19]. 
To answer this question the concept of corporate governance emerged especially after some scandals occurred in the financial sector and which inevitably questioned how large organisations and the capital market itself are managed. The actual aim of governance is to implement some principles that nowadays are also important social values, namely, transparency, accountability and empowerment of all stakeholders [20].

In private corporations the key issue focuses on the possibility of the shareholders and other stakeholders being able to ensure that the management of the business is performed according to universal ethical principles and with pre-established goals. With regard to public entities, social accountability is substantially enhanced, and respect for organisational values and transparency in management become particularly relevant. As stated by Coyle about the relevance of corporate governance for non-corporate organizations, "many of the issues of corporate governance also apply, however, to smaller companies, and to non-corporate organisations such as state-owned enterprises, government departments and bodies, institutes and associations, and charitable organisations. Such organisations also face the central dilemma of corporate governance: how rights and responsibilities are shared and exercised by different groups to ensure common objectives. For example, whereas a company should be run in the interests of its owners, a government organisation should be run in the interests of the general public and in pursuit of the aims of the government itself" [21]. Corporate governance should be understood as the set of relationships between the administration of an organisation, shareholders and other stakeholders, referring both to the structure through which to determine the goals of an organisation (and the means to achieve them) and the monitoring of organisational performance [22]. That is, corporate governance is concerned with both the internal aspects of an organisation (internal control, interests of the shareholders) and with its external aspects (relations with the other stakeholders).

According to Mallin, there are various theories that can justify the need for corporate governance, in particular the agency theory and the stakeholder theory. Given the asymmetry of information, the convergence of interests between agent and principal is not always easy, so the control by corporate governance is essential to monitor performance at managerial level [23]. These theories are based on the assumption that many interest groups, internal and external (stakeholders), are affected by the performance of an organisation, with some directly associated with it, while others only establish relationships in a roundabout way. Thus, the shareholders, the owners of the invested capital, are the ones most interested in making a profit from their investment. There are therefore strong agency relationships between these (principal) and the administrators (agent). One drawback of this agency relationship is that the agent may have different motivations from the shareholders' and, consequently, the expected return on the investment does not take place.

In fact, since the $19^{\text {th }}$ century the industrialization of Western societies led to the separation of capital ownership and corporate management, particularly those that are listed on the stock exchange. This concern has occurred mainly in the United States of America and the United Kingdom, where the legal system based on common law gives great protection to the minority shareholders, thus allowing expanding the base of support to small investors. In countries with a Roman-Germanic legal tradition (France, Italy, Spain, etc.), based on the civil code, there is a greater codification of the standards but perhaps a less protection of the rights of minority shareholders, and therefore, less tendency to invest in the capital market.

Beyond the binomial shareholder/board there are other stakeholders in the good performance of an organisation. In fact, the stakeholder theory states that maximizing the profit and dividends of shareholders is a necessary condition, but not sufficient, for ethical governance of a company, in particular in a liberal democracy, which must comply with a wide range of options and perspectives. That is, the main characteristic of any organisation is that it is formed by a group of people who share a common goal (the corporate mission). Therefore, the whole is more than the sum of the separate parts, and the human resources become the soul of an organisation and constitute its main asset. As a result, employees are interested in the success of the organisation for several reasons. On the one hand, due to the salaries they earn and that ensure their livelihood. On the other hand, due to the direct future benefits, such as pensions (if applicable) or indirect, the image that the organisation has in society (emotional salary), that makes employees have a vested interest that this image is projected in the community.

Other stakeholders interested in the success of an organisation are financial institutions and other providers of goods and services. Everyone has a vested interest in its good economic performance and compliance with its commitments. Their main concern its good performance of the institutions to which they belong. For instance consumers, local communities in which the organisations are located (including associations of consumer protection, etc.) are also interested in their success.

On the other hand, there is frequently a principal-agent problem in any delegation of power and IRAs are no 
exception. This problem, in independent regulation, grows out of the separation of democratic legitimacy and regulatory control. It follows that governance arrangements in independent regulation should supply an adequate monitoring and supervision system. And recent trends on organizational sociology have largely advocated an open systems perspective [5] [24]. Different governance practices may be more or less effective depending on the contexts of different organizational environments but a set of common principles should always be followed irrespective of the environment and regulation-related actors. Accountability is a principle instrumental for adequate governance that should be in the core of the key objectives of regulatory governance [25].

The term accountability refers both to the need to make the decision-making process visible and transparent and the method to achieve this goal. Accountability has, from a theoretical point of view, two distinct though related aspects. Public accountability means the obligation to involve both society in general and citizens in particular in decisions that concern them, in particular with regard to the establishment of explicit priorities. Democratic accountability refers to the process by which a public body (or other organisation) - namely an IRA - is held accountable to society. By society it is meant both the people as well as its elected representatives such as the parliament or other political institution. What may be at stake is the preparation of periodic reports, performing internal and external audits, or even an explanation of a particular course of action, including the adoption of guidelines or other procedural rules. In essence, what should be taken into consideration is the application of procedural rules. That is, the choices and regulatory decisions must be transparent, public and periodically subjected to an external audit process with well-defined rules. This perspective is based on the concept of accountability and allows justifying the scope and limitations of the various decisions. So, all stakeholders have the right to know the principles underlying the decision-making process and, in addition, to be active partners in that process. It is the application of the concept of democratic and transparent process and to promote the participation of society which has the necessary wisdom to decide in this and in other areas of social importance [26].

With the implementation of accountability the principle of autonomy is established, not only individually but also collectively. Society's autonomy in relation to the institutions with (or without) democratic legitimacy and promote the right to information for all stakeholders. In an extreme version of citizen participation, it may even mean the objective and direct transfer of power to society, i.e. the empowerment of specific stakeholders [27]. However, the implementation of methods of participation of the population in the decision-making process, in particular with regard to certain minorities, must bear in mind that the majority of citizens do not have enough information to decide in a truly informed way. In fact, transparency and accountability converge so that the vertex of the regulatory activity is the citizen in an ever-changing society.

Regulatory governance - in accordance with the principles of transparency, responsibility, accountability and stakeholders' empowerment-is a fundamental tool for the introduction of the new public management. Regardless of the type of regulator involved being, or not, an agency with more or less independence from the political power, there must be effective control mechanisms that allow the citizens to trust the regulator's ability to intervene. In the case of an independent entity, governance is particularly important, given the lack of direct or indirect control and the diminished political accountability associated with this type of authority. The general characteristics of regulatory governance are:

1) Ensure the existence of an adequate system of control of the regulatory agency;

2) Prevent the abuse of power by a single individual;

3) Monitor existing relations between the management of the regulatory agency, its administration and stakeholders;

4) Ensure that the regulatory agency is managed according to the best interests of the stakeholders;

5) Encourage both the transparency and accountability that society expects in the management and performance of the regulatory agency.

In accordance with the principle of explicit accountability sunshine regulation is vital for an effective regulatory activity, for an appropriate supervision of the different providers, to avoid quality shading problems and for healthy competition in any economic sector. In this way IRAs will be properly seen as a fundamental tool in democratic politics and their decisions will be more promptly respected. The principles for effective governance in regulation are as follows:

1) Goals of Regulatory Governance: to increase the performance of the regulatory agency, to assure its social responsibility namely concerning the search for the common good, and to promote conformance with regards accountability arrangements in a fair and transparent way; 
2) External Controls (sunshine regulation): a) Public Accountability: Explicit, public detailed procedures for evaluating the regulator with full public report (use reports, performance reports, compliance reports and consultants), global budgeting, fair grievance procedures (legal and non-legal), and adequate privacy protection; b) Democratic Accountability: Auditing by political representatives such as the Parliament Select Committee. In this way both democratic accountability and political accountability are assured; c) Other External Controls: External mechanisms of reporting, public disclosure of the processes and rationale adopted in regulation, external audit, financial account and annual report (published at internet);

3) Internal Controls: a) Self-Regulation: Internal audits, ethical codes and disclosure of directors' performance and remuneration; b) Board: Unitary board, mechanisms of appointment to the board (public contest), and performance evaluation.

As a general rule, common to all corporate governance strategies, the existence of internal and external control mechanisms of the functioning of the organisation must be pointed out [21]. The transparency of the decision-making process and the related rationale is of the greatest relevance to ensure citizens a total equity in the treatment of complex relationships that develop in society, particularly those which relate to compliance with the rules of the competitive market [28].

It would be great for democratic transparency if, in countries that are introducing the use of IRAs, the parliament (or equivalent in non-parliamentary systems) exercised closer monitoring on all areas of regulation. In addition to the method of appointment of governing bodies, hearings in parliamentary committee is essential for effective scrutiny of the performance of independent regulatory authorities [29]. The independence of regulatory authorities does not make them immune to parliamentary monitoring. Parliamentary monitoring at committee level less politicized and more technical can be an appropriate compensation for the absence of Government control. The internal control of activity may be exercised by two distinct pathways. On the one hand, by the nature of the board of directors that, being collegiate (a president and two or more members), implies that decisions are by majority, preventing any totalitarian temptation on the part of one of its members. On the other hand, the statutory auditor should have the task of ensuring the legality and the economy of financial and asset management. The statutory auditor must be a chartered accountant or firm of chartered accountants.

Another internal control mechanism might be the establishment of an advisory board composed of representatives of institutions such as professional associations, public agencies, representatives of users and representatives of other associations of the regulated sector. But great caution is required since the choice of certain personalities is always difficult in a context of transparency and effective accountability to society. When setting up a body of this nature, it is important to hear the stakeholders, whoever they may be, and willingly accept their suggestions or complaints.

To sum it up, regulatory governance is particularly prominent in the institutional framework of IRAs. There are internal and external control mechanisms that prevent any situation of abuse of authority and prevent the capture of the regulator by the political power or by economic agents. Although political accountability is somewhat diluted, this can be done through a rigorous control in parliamentary committee, the highest body for the exercise of democratic power in many political systems. The institutional format must be suitable for the purpose for which they are designed, namely independent regulation in different sectors of economic activity. The state should have as its primary mission to guide the structural policy and not organize their production that is more steering and less rowing [30].

\section{Conclusions and Suggested Measures}

The Organisation for Economic Cooperation and Development (OECD) has suggested that one of the more diffused institutions in the modern regulatory governance is the so-called independent regulator. Indeed, the inexorable presence of market failures means that competition is never perfect in sectors such as utilities [31]. That is, the role of the regulator is essential to ensure that the irruption of market mechanisms assures equity and fairness, always guaranteeing economic efficiency. Independent regulation is usually undertaken to correct various types of market failures: failure of competition, negative externalities, information asymmetry, and insufficient provision of public goods and services, such as electricity, healthcare or even national defense. The existence of incomplete markets makes it an imperative to administer a regulatory contract in the interest of all the stakeholders of a specific market [3]. In this perspective, some measures suggested in this study could be synthesized as follows:

A) In countries with a liberal economy, the design of regulatory agencies, both across countries and across 
sectors, could be enhanced at least in some essential aspects. Appropriate governance model does depend on conditions in the specific sector, and in particular, in the specific country [6] [7]. There may be common general principles that should be incorporated in the design of these organizations, so that independent regulators fulfill their objectives in any political system, namely in parliamentary systems or presidential systems. For instance, regulation of some economic sectors, even with a high degree of independence, should be accountable to elected politicians in any democratic political system. Also, the way regulators are selected is also a fundamental step to ensure political and economic independence;

B) IRAs - as nonmajoritarian institutions in democratic politics - should also be controlled by society, and its activity should be at arm's length from the government at least in two different ways (namely in southern countries that are beginning to implement regulatory governance) [32]. If strengthening accountability arrangements is by far the most important mechanism that guarantees regulators' autonomy from the government and regulated organisations, the way regulators have chosen can also deeply influence independence in regulation;

C) Board accountability can be enhanced by the generalization of the principle of the public contest of regulators. In this way the best regulators can be chosen amongst the pool of specialists in any specific economic area;

D) The institutional-design suggested in this study relies upon a model of governance, where IRAs are governed by a board of directors that are accountable to elected institutions and elected representatives. It remains to be seen if the existence of an advisory board adds value to this governance model, as suggested by Thatcher, "an analysis of four European nations between 1990 and 2001 shows that elected politicians do not use their powers to appoint party politicians, force the early departures of IRA members, reverse IRA decisions, or reduce IRA budgets and powers" [8];

E) This governance model can be generalized to different economies, namely economies in transition can benefit with this rationale. It remains to be seen if in special economic and political environments - such as the Mercosul (Southern Common Market) - the independent regulator can be chosen by international open tender. Moreover, the board composition and the director profile are of utmost importance to guarantee full IRA independence in transnational regulatory networks.

However, there are limitations of this study, namely with regard to the reproducibility at a world level of many of the proposed suggestions. Also, different political regimes and democratic arrangements could originate different conclusions in some of the assertions of this paper. Nevertheless, this perspective and these suggestions may have managerial implications at the level of the organizational processes of IRAs, but further studies are needed to confirm its utility.

\section{References}

[1] Boyne, G., Farrell, C., Law, J., Powell, M. and Walker, M. (2003) Evaluating Public Management Reforms. Open University Press, Buckingham.

[2] Nunes, R., Rego, G. and Brandão, C. (2010) Public Accountability and Sunshine Healthcare Regulation. Health Care Analysis, 19, 352-364. http://dx.doi.org/10.1007/s10728-010-0156-6

[3] Ayres, I. and Braithwaite, J. (1992) Responsive Regulation. Transcending the Deregulation Debate. Oxford University Press, Oxford.

[4] Baldwin, R. and Cave, M. (1999) Understanding Regulation. Theory, Strategy and Practice. Oxford University Press, Oxford.

[5] Aguilera, R., Filatotchev, I., Gospel, H. and Jackson, G. (2008) An Organizational Approach to Comparative Corporate Governance: Costs, Contingencies, and Complementarities. Organization Science, 19, 475-492. http://dx.doi.org/10.1287/orsc.1070.0322

[6] Thatcher, M. (2002) Regulation after Delegation: Independent Regulatory Agencies in Europe. Journal of European Public Policy, 9, 954-972. http://dx.doi.org/10.1080/1350176022000046445

[7] Thatcher, M. (2002) Delegation to Independent Regulatory Agencies: Pressures, Functions and Contextual Mediation. West European Politics, 25, 125-147. http://dx.doi.org/10.1080/713601588

[8] Thatcher, M. (2005) The Third Force? Independent Regulatory Agencies and Elected Politicians in Europe. Governance, 18, 347-373. http://dx.doi.org/10.1111/j.1468-0491.2005.00280.x

[9] Dubash, N.K. and Morgan, B. (2013) The Rise of the Regulatory State of the South. Infrastructure and Development in Emerging Economies. Oxford University Press, Oxford. http://dx.doi.org/10.1093/acprof:oso/9780199677160.001.0001 
[10] Majone, G. (1994) The Rise of the Regulatory State in Europe. West European Politics, 17, 77-101. http://dx.doi.org/10.1080/01402389408425031

[11] Majone, G. (1997) From the Positive to the Regulatory State. Journal of Public Policy, 17, 139-167. http://dx.doi.org/10.1017/S0143814X00003524

[12] Majone, G. (2010) Regulation and Public Policy. Gestão da Saúde, Gráfica de Coimbra, Coimbra.

[13] Crew, M. (1999) Regulation under Increasing Competition. Kluwer Academic Publishers, Boston. http://dx.doi.org/10.1007/978-1-4615-5117-1

[14] Walshe, K. (2003) Regulating Healthcare. A Prescription for Improvement? State of Health Series, Open University Press, Maidenhead.

[15] Kon, J. (2003) Understanding Regulation and Compliance. Securities Institute Services, London.

[16] Gilardi, F. (2004) Institutional Change in Regulatory Policies: Regulation through Independent Agencies and the Three New Institutionalisms. In: Jordana, J. and Levi-Faur, D., Eds., The Politics of Regulation: Institutions and Regulatory Reforms for the Age of Governance (The CRC Series on Competition, Regulation and Development), Edward Elgar Publishing Limited, Cheltenham, 67-89.

[17] Boyer, R. and Saillard, Y. (2002) Regulation Theory: The State of the Art. Routledge, London.

[18] Selznick, P. (1985) Focusing Organisational Research on Regulation. In: Noll, R., Ed., Regulatory Policy and the Social Sciences, University of California Press, Berkeley, 363-364.

[19] Boatright, J. (2003) Ethics and the Conduct of Business. 4th Edition, Prentice Hall, Englewood Cliff.

[20] Colley, J., Doyle, J., Logan, G. and Stettinius, W. (2003) Corporate Governance: The McGraw-Hill Executive MBA Series. McGraw-Hill, London.

[21] Coyle, B. (2003) Corporate Governance, ICSA Professional Development Corporate Governance 2003-2004. ICSA Publishing Ltd., London.

[22] Cadbury, A. (2002) Corporate Governance and Chairmanship: A Personal View. Oxford University Press, Oxford. http://dx.doi.org/10.1093/acprof:oso/9780199252008.001.0001

[23] Mallin, C. (2004) Corporate Governance. Oxford University Press, Oxford.

[24] Aguilera, R., Goyer, M. and Kabbach, L.R. (2012) Regulation and Comparative Corporate Governance. In: Wright, M., Siegel, D.S., Keasey, K. and Filatotchev, I., Eds., Handbook of Corporate Governance, Oxford University Press, Oxford, 23-45. http://dx.doi.org/10.4135/9781446200995.n18

[25] Hopt, K. (2011) Comparative Corporate Governance: The State of the Art and International Regulation. The American Journal of Comparative Law, 59, 1-73. http://dx.doi.org/10.5131/AJCL.2010.0025

[26] Whincop, M. (2001) Bridging the Entrepreneurial Financial Gap: Linking Governance with Regulatory Policy. Ashgate Publishing Limited, Burlington.

[27] Goodman, J. and Musgrave, G. (1992) Patient Power: Solving America's Health Care Crisis. CATO Institute, Washington DC.

[28] Federowicz, A. and Aguilera, R. (2003) Corporate Governance in a Changing Economic and Political Environment: Trajectories of Institutional Change. Palgrave Macmillan, New York. http://dx.doi.org/10.1057/9780230286191

[29] Sur, S., Lvina, E. and Magnan, M. (2013) Why Do Boards Differ? Because Owners Do: Assessing Ownership Impact on Board Composition. Corporate Governance: An International Review, 21, 373-389.

[30] Saltman, R. and Busse, R. (2002) Balancing Regulation and Entrepreneurialism in Europe's Health Sector: Theory and Practice. In: Saltman, R., Busse, R. and Mossialos, E., Eds., European Observatory on Health Care Systems, Regulating Entrepreneurial Behaviour in European Health Care Systems, Open University Press, Buckingham, 3-52.

[31] Organization for Economic Cooperation and Development (2002) Regulatory Policies in OECD Countries: From Interventionism to Regulatory Governance. OECD, Paris.

[32] Soltani, B. and Maupetit, C. (2013) Importance of Core Values of Ethics, Integrity and Accountability in the European Corporate Governance Codes. Journal of Management \& Governance, Published Online. http://dx.doi.org/10.1007/s10997-013-9259-4 
Scientific Research Publishing (SCIRP) is one of the largest Open Access journal publishers. It is currently publishing more than 200 open access, online, peer-reviewed journals covering a wide range of academic disciplines. SCIRP serves the worldwide academic communities and contributes to the progress and application of science with its publication.

Other selected journals from SCIRP are listed as below. Submit your manuscript to us via either submit@scirp.org or Online Submission Portal.
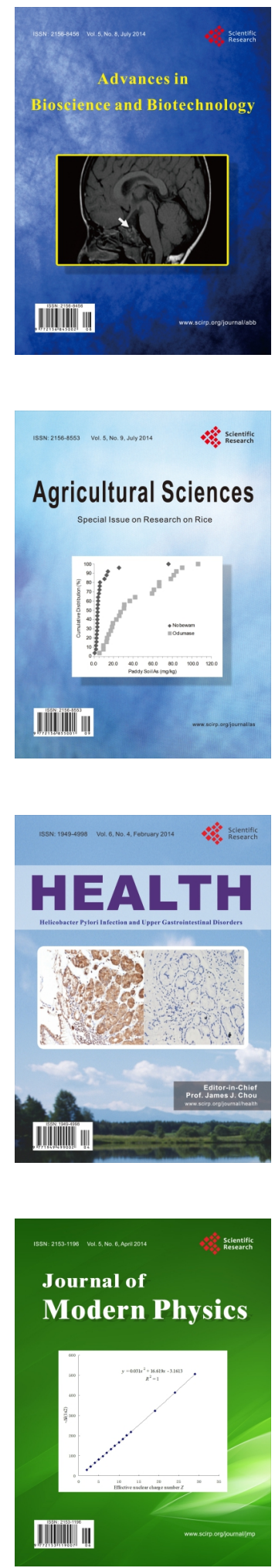
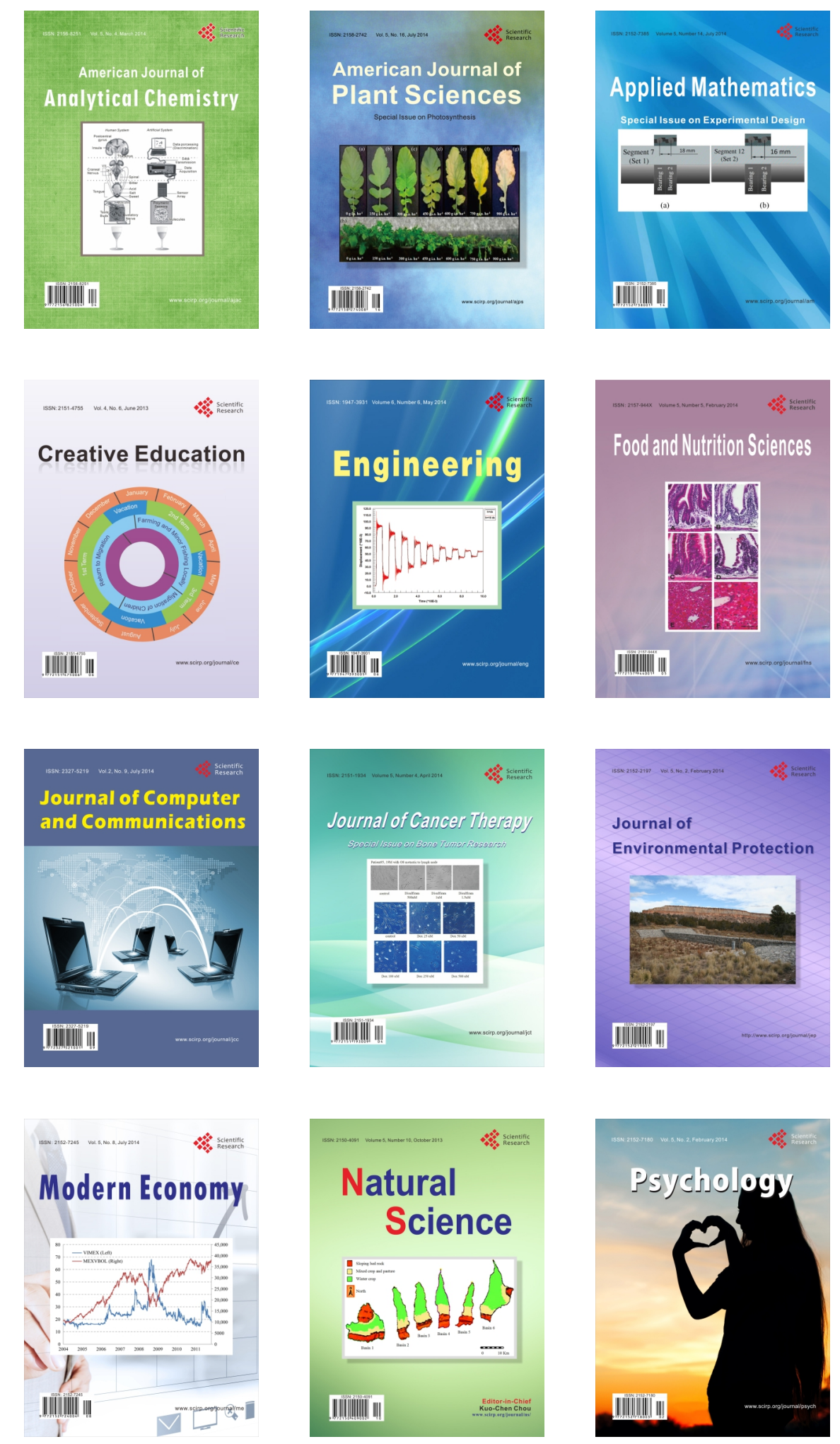